\title{
The use of mediation procedure in dispute resolution processes of the UEFA Financial Control Body and the Court of Arbitration for Sport
}

\section{E. A. Shabalina}

For citation: Shabalina, Ekaterina A. 2018. "The use of mediation procedure in dispute resolution processes of the UEFA Financial Control Body and the Court of Arbitration for Sport". Vestnik of Saint Petersburg University. Law 1: 67-77. https://doi.org/10.21638/11701/spbu14.2018.105

The article analyzes the practice of applying mediation in the field of sports conflicts in the framework of dispute resolution in the Court of Arbitration for Sport. The article presents research of issues that have become subjects of mediation in the field of sports, including analysis of the cases of successful application of mediation and the identification of the reasons for failed or unsuccessful attempts to settle the dispute with the help of an intermediary. The authors note mediation is represented as a way of resolving various sports disputes ranging from claims arising from contractual obligations to the requirements for control and application of disciplinary measures, none of which are particular to the conciliation procedures according to the general rule. This thereby reflects a number of features of mediation within the framework of sports conflicts.

Keywords: sports mediation, sports law, sports conflict, Court of Arbitration for Sport, CAS, procedural rules governing the UEFA Club Financial Control Body.

At the current time the concept of alternative dispute resolution has now become a general legal trend throughout the world community. Among the methods of alternative dispute resolution, mediation is one of the most recent and dynamically developing ones. Traditionally, commercial and entrepreneurial disputes are considered to be a classical field of mediation, but gradually the scope of this institution has gone beyond these boundaries (Susskind and Kovick, and Harvey, and Brown 2009).

Disputes in the field of sports relations also present the possibility of a peaceful settlement. It is impossible not to note that the procedure of mediation in sports disputes has specific features in connection with the peculiarities of the relations themselves, including disputes, in the field of sports.

First of all, in sports relations there are particular issues related to the composition of the disputants. In addition to athletes and clubs, there are also sports leagues, federations, agents, sponsors, TV and radio channels.

Secondly, the regulation of sports relations consists of the norms of civil law, commercial law, employment and labor law, administrative law, tax law, the norms of sports organizations (so called "sports law").

Thirdly, sports conflicts cannot be settled by one single procedure. Disputes in the field of sports can be resolved by negotiations, courts of general jurisdiction, sports arbitration courts and authorized bodies of sports federations. Almost any procedure can be completed using mediation.

(c) Санкт-Петербургский государственный университет, 2018 
In connection with so many opportunities to settle a sport dispute, there arises the natural question about the possible conflict of procedural rules of different jurisdictional bodies in terms of the parties choosing mediation and its procedure (Mordehai 2017, 131-134).

For example, at first sight there is a conflict of jurisdictions - the CAS Mediation Rules of the International Council of Sports Arbitration and Procedural Rules Governing the UEFA Club Financial Control Body.

However, according to Article 1 CAS Mediation Rules of the International Council of Sports Arbitration, CAS mediation is provided for the resolution of contractual disputes. Disputes related to disciplinary matters (doping issues, match-fixing and corruption) are excluded from CAS mediation. However, in certain cases, where the circumstances so require and the parties expressly agree, disputes related to other disciplinary matters may be submitted to CAS mediation.

In connection with this, it is necessary to interpret the Recommended clause for CAS Mediation to be inserted in a contract, according to which "... any dispute, any controversy or claim arising under, out of or relating to this contract and any subsequent amendments of or in relation to this contract" as a rule only on contractual disputes. This is proved by following sentence of the Recommended clause: “... including, but not limited to, its formation, validity, binding effect, interpretation, performance, breach or termination" (Court of Arbitration for Sport 2017).

Now therefore if the parties have decided to conclude a mediatory agreement or to include a mediatory clause in the contract, they extend its effect on contractual relations. If the parties want to apply the CAS mediation procedure to resolve disciplinary issues, they must indicate this additionally.

In turn, the Procedural Rules Governing the UEFA Club Financial Control Body (hereafter - the Procedural Rules) have their own direction and specificity (Procedural Rules Governing the UEFA Club Financial Control Body. Accessed July 14, 2017. https:// www.uefa.com/insideuefa/documentlibrary/index.html).

On the one hand, the scope of the Procedural Rules is more limited than the CAS Mediation Rules (hereafter - the Mediation Rules). The Procedural Rules regulate only football relations, while the Mediation Rules can be used in disputes arising from sports relations in other competitions.

On the other hand, the Mediation Rules regulate only the mediation procedure, just as the Procedural Rules provide for other forms of settlement of disputes fall within this Rules.

However, the mediation procedure also has a place in the Procedural Rules. So in accordance with Art. 14 (1) (b) and 15 (1), upon termination of the investigation by the financial control body of UEFA, the investigator, after consulting with other members of the investigating chamber, may decide, inter alia, on concluding an amicable agreement with the defendant's consent.

This is exactly the point of contact between the two sources of legal regulation which gives the impression of a conflict of jurisdictions.

However, the Mediation Rules and the Procedural Rules have a different focus. The Mediation rules, as has been previously said, are aimed at resolving contractual disputes, but the Procedural Rules have a controlling nature, as evidenced by their title and also Art. 3 of Procedural Rules according to which the Rules are intended to determine whether the 
licensors meet the criteria for issuing licenses to the club as well as the subsequent determination of whether the licensees fulfill the requirements for the financing of the club.

It should be noted that the procedure of mediation, how it is used in the Mediation Rules, are not universal. Of course, now the scope of application of mediation in the general went far beyond what was traditional for this procedure, namely contractual disputes, gradually mediation has become used to resolve administrative and tax disputes (Folberg 1994, 46). However, where there is an exact, step-by-step procedure determined by the legislator, there is no scope for mediation. This should be taken into account, determining in each individual case the possibility of applying mediation in disputes over disciplinary liability.

According to the results of the violations identified by the UEFA Financial Control Authority in accordance with Art. 15 Procedural Rules it is possible to conclude settlement agreements. These agreements are of a special legal nature, because they are intended to resolve issues of possible legal exposure rather than resolution of contractual disputes. This responsibility, to say the least is of a quasi-public nature, because UEFA is an international organization that regulates relations in the field of football as a sport.

The settlement agreement, which is part of the response of the UEFA Financial Control Authority to the club's violation of the order and terms of financing, according to Art. 14 (1) (b) and 15 include, but are not limited to, the factors specified in Annex XI to the UEFA Regulation Club Licensing and Financial Fair Play: the quantum and trend of the break-even result, impact of changes in exchange rates, projected break-even result, budgeting accuracy, debt situation, force majeure and Financial Fair Play (UEFA Regulation Club Licensing and Financial Fair Play. Accessed July 14, 2017. https://www.uefa.com/ insideuefa/documentlibrary/index.html).

Such agreements are concluded in circumstances that require the conclusion of an effective, fair and beneficial settlement without transfer of a case to the jurisdictional chamber and are aimed at ensuring the break-even of the clubs with minimal delay.

For the foregoing reasons, mediation and peaceful settlement in sports law are not different alternative forms of dispute resolution, do not repeat each other, nor do they create a conflict in their application.

This is shown by settlement agreements with individual clubs, concluded on the basis of the UEFA club financial monitoring process, for example the Settlement Agreement with Fenerbahçe Futbol, with Trabzonspor Sportif Yatirim ve Futbol Isletmeciligi Ticaret, with FC Astana, with GNK Dinamo Zagreb (May 2016), with Sporting Clube de Portugal, with FC Lokomotiv Moskva, with Kardemir Karabükspor, with FC Rostov, with FC Krasnodar, with PFC CSKA Sofia, with AS Roma, with AS Monaco FC (May 2015) (The UEFA Club Financial Control Body Cases 2017).

These settlement agreements contain a clause that the final decisions of the jurisdictional chamber that can be appealed in case of breach by one party of the terms implied by settlement agreement, can be appealed in accordance with regulations the Code of Sports-related Arbitration (hereinafter - CAS) in accordance with Article 34 (2) of the Regulation. Besides, any dispute related to the settlement agreements, including regarding the validity of the treaty, compliance with commitments and interpretation must be decided by the UEFA Financial Control Authority. Only when all the UEFA remedies have been exhausted may CAS have exclusive jurisdiction of decision making. 
In summary the CAS mediation procedure and settlement agreements of the UEFA Financial Control Authority are distinct procedures that do not substitute each other.

How often the parties to a sport dispute resort to CAS mediation procedure is also a pertinent issue. Despite the obvious advantages of settling the dispute through the application of the mediation procedure, practice shows that not all conflicts in the field of sports relations are successfully resolved through mediation.

We analyzed eleven decisions in which either one of the parties tried to resort to an attempt at a settlement agreement of the dispute, or the sports arbitration attempted to send the parties into the search for a mutually acceptable solution. Only in three decisions (Arbitration CAS 2015/A/4220 Club Samsunspor v. Aminu Umar \& Fédération Internationale de Football Association (FIFA), award of 12 July 2016; Arbitration CAS 2014/A/3850 Branislav Krunic v. Bosnia and Herzegovina Football Federation (BIHFF), award of 17 July 2015; Arbitration CAS 2015/A/4148 \& 4149 \& 4150 Sheffield Wednesday FC v. Louletano Desportos Clube and International Clube de Almancil \& Associação Academica de Coimbra, award of 17 February 2016) were the parties able to agree on the choice of the mediatory procedure instead of trial, and only in one case (Arbitration CAS 2015/A/4148 \& 4149 \& 4150 Sheffield Wednesday FC v. Louletano Desportos Clube and International Clube de Almancil \& Associação Academica de Coimbra, award of 17 February 2016) did the attempt at an alternative dispute resolution end successfully, and parties managed to reach a mutually acceptable decision regarding the subject of the conflict (here and below all cited court rulings are given in connection with an inquiry system "Court of Arbitration for Sport". Accessed November, 1, 2017. http://www.tas-cas.org/en/ jurisprudence/archive.html).

In four of the eight failed cases of mediation (Arbitration CAS 2014/A/3643 Club Promotora del Pachuca S. A. de C. V.v. Facundo Gabriel Coria and FIFA, award of 5 June 2015 and Arbitration CAS 2014/A/3707 Emirates Football Club Company v. Hassan Tir, Raja Club and FIFA, award of 19 June 2015), one of the parties did not express any relation to the possibility of settling the dispute through a world procedure, and in two of them it was FIFA (Arbitration CAS 2015/A/4137 Olympique Lyonnais v. AS Roma, award of 16 November 2015, Arbitration CAS 2014/A/3679 FC Dacia Chisinau v. Goran Stankovski, award of 27 February 2015, Arbitration CAS 2015/A/4346 Gaziantepspor Kulübü Derneği v. Darvydas Sernas, award of 5 July 2016, Arbitration CAS 2014/A/3642 Erik Salkic v. Football Union of Russia (FUR) and Professional Football Club Arsenal). In four cases, one of the parties was against the attempts of the other party to resort to mediation (Arbitration CAS 2015/A/4137 Olympique Lyonnais v. AS Roma, award of 16 November 2015, Arbitration CAS 2014/A/3679 FC Dacia Chisinau v. Goran Stankovski, award of 27 February 2015, Arbitration CAS 2015/A/4346 Gaziantepspor Kulübü Derneği v. Darvydas Sernas, award of 5 July 2016, Arbitration CAS 2014/A/3642 Erik Salkic v. Football Union of Russia (FUR) and Professional Football Club Arsenal).

One of the main conditions for mediation of any legal conflicts is the mutual interest of the parties in the mediation procedure and their consent to its conduct.

Sometimes one of the parties actively looks for a way to settle the dispute peacefully. While the second party avoids this, reacting silently to proposals to resort to mediation.

For example, in the case Arbitration CAS 2014/A/3580 A.C. Cesena S. p.A.v. Tokyo Football Club, award of 24 December 2014 and Arbitration CAS 2015/A/4057 Maritimo da Madeira Futebol SAD v. Al-Ahli Sports Club, award of 30 November 2015. 
It is possible to trace the reasons for the silence of the second party in response to proposals and even numerous requests (for example, in the case Arbitration CAS 2014/A/3580), noting certain regularities in the decisions under consideration.

Both disputes concern the issue of changing the order of payment and interest for the transfer of the player (in the case Arbitration CAS 2015/A/4057 there is still a question of payment of penalty).

Factual allegations of the cases are similar: after the transfer of a football player, the club could not pay for the acquisition of the right to register the player in accordance with the agreed payout schedule in the transfer contract.

In the case Arbitration CAS 2014/A/3580 notes that FC Cesena S.p.A. does not dispute the fact of transfer of the player and the fact of having a debt to FC Tokyo Football Club. Its requirements do not include clarification of the appeal, its cancellation or change, the club requests an oral hearing in CAS to be heard by the second party about the unstable financial condition of the club as a basis for reviewing the schedule of payments.

In the case Arbitration CAS 2015/A/4057 FC Al-Ahli Sports Club also does not dispute the fact of non-payment of the last of the three tranches for transferring of right to register a football player, but it refuses to make this tranche owing to claims to the second side of the dispute, FC Maritimo da Madeira Futebol SAD, regarding the payment of solidarity contribution. The payment of solidarity contribution functions successfully in the football world. Its essence lies in the fact that the football club (school) that brought up the football player during the whole of his career receives a certain part of the transfer amount of this football player ( $5 \%$ of the transfer amount of the football player is distributed between the clubs participating in the player's training). Until recently, the mechanism of solidarity acted only with international transitions of football players, but it has since spread to the internal transitions of players. So since 2011, with the adoption of the new Regulations of the RFU on the status and transitions (transfer) of football players, the mechanism of solidarity has appeared also with domestic transfers.

In both the situations described, the defendant (FC Tokyo Football Club in the first case and FC Al-Ahli Sports Club in the second) evaded attempts to settle the dispute peacefully. The reason is that in both cases the fact of having a debt was not denied by both parties to the dispute, and was also confirmed in the course of the previous dispute resolution process in jurisdictional bodies.

However, in the case Arbitration CAS 2014/A/3580 FC Tokyo Football Club was not interested in providing FC Cesena S. p.A. the ability to change the schedule of debt repayment in order to prevent bankruptcy of the club. It is particularly disturbing that this categorical position of FC Tokyo Football Club cannot be excused. Should the club file for bankruptcy, the opponent cannot get the whole amount of debt, nor get anything that turns the court decision in its favor a "Pyrrhic victory".

This makes it seem even more pragmatic to ignore the FC Al-Ahli Sports Club mediation procedures: the mutual monetary claims of the parties are obvious, including the debt of FC Al-Ahli Sports Club to the plaintiff.

If the club did not shy away from mediation, it would have a chance to substantiate its counter monetary claims to the plaintiff in the course of a dialogue under the guidance of a professional mediator and the parties could, perhaps through mutual concessions, peacefully resolve their conflict: offset counter-claims and setting debt repayment installments. As a result of the arbitration, neither party received full satisfaction of its claims: 
FC Al-Ahli Sports Club did not receive a set-off of solidarity payments, and the plaintiff of FC Maritimo da Madeira Futebol SAD the full amount of penalties for delay in payment.

It should be noted that in the doctrine and practice the position prevails according to which mediation is not a comprehensive procedure equally suitable for any dispute. Parties can not apply the procedure of mediation if there is an exact step-by-step procedure determined by the legislator to resolve a dispute of a specific category. However, in the area of sports disputes, there is a different trend, which can be traced in the decisions of the Court of Arbitration for Sport. For example, in the case Arbitration CAS 2015/A/4137 Olympique Lyonnais v. AS Roma, award of November 16 2015, the parties tried to independently agree on the method of calculation and the method of payment of solidarity contribution. However the FIFA Dispute Resolution Chamber, when considering the dispute, ruled that the FIFA Regulations on the Status and Transfer of Players superseded any clause of the transfer agreement of the player and that the parties could not depart from the legal regime established in the Procedural Rules (FIFA Regulations on the Status and Transfer of Players. Accessed July 14 2017. http://www.fifa.com/governance/dispute-resolution-system/index.html). This decision was successfully appealed in the CAS, which indicates the broad possibilities of the parties in the application of mediation in sports disputes. However, in this case one of the parties - the plaintiff FC Olympique Lyonnais categorically refused to offer the defendant of FC Roma to resolve the dispute in CAS through the mediation procedure. Perhaps the negative experience of trying to reach a mutually beneficial independent decision in the FIFA Dispute Resolution Chamber influenced it.

As previously noted mediation is possible only when the parties are mutually interested in finding a solution that is beneficial to both parties to the conflict. However, there are decisions in which the contending parties (football clubs or club and player) express their desire to resolve the dispute during mediation, but this is hampered by the lack of response from FIFA.

One example is the case Arbitration CAS 2014/A/3643 Club Promotora del Pachuca S.A.de C.V.v. Facundo Gabriel Coria and FIFA, award of 5 June 2015 and Arbitration CAS 2014/A/3707 Emirates Football Club Company v. Hassan Tir, Raja Club and FIFA, award of 19 June 2015. In these cases FIFA acted on the side of the defendants since the appellants challenged not only the actions of the club and (or) the player but also the decisions that were taken by the FIFA Dispute Resolution Chamber.

The subject of the above disputes is the unilateral termination of an employment contract by a player with a football club. For each case, players said that the termination of employment contracts was legitimate because the club did not fulfill its obligations to ensure safeguards for the rights of labor or, in other words, his actual employment. FC Club Promotora del Pachuca S. A. de C. V. and FC Emirates Football Club Company, in turn, said that their players illegally terminated the employment contract ahead of schedule. In both these decisions, both the club and the player ask for the application of disciplinary sanctions to the opposite side.

In general, the mediation procedure is inherent in labor disputes, as their parties are aimed at continuing the relationship or to a decent way out of them, which is especially important for the relations of players and clubs, since they cannot but value their reputation and the desire to cooperate with them. To a greater extent, the advantages and benefits of a peaceful settlement of a dispute (saving time, money, the ability to "save one's 
blushes") are understood by football clubs rather than players. For example, in decisions Arbitration CAS 2014/A/3679 FC Dacia Chisinau v. Goran Stankovski, award of 27 February 2015 and Arbitration CAS 2015/A/4346 Gaziantepspor Kulübü Derneği v. Darvydas Sernas, award of 5 July 2016, in which the dispute is the legitimacy of the player's early termination of the contract, it was the clubs which insisted on the mediation procedure while the players categorically objected. Perhaps the reason for this is the pragmatic nature of clubs which, due to the long-term stay in the professional arena (in contrast to the players' relatively short term careers), argues for more concern for financial health and image. And this is also possibly evident in the players' distrust of the mediation procedure. Therefore, it is very significant that in the above cases both clubs and players agreed to the CAS proposal to settle the conflict by the mediation procedure.

However, FIFA did not respond to the proposition made by the other participants in the dispute to resolve it peacefully. It should be noted that the position of FIFA regarding unilateral termination of an employment contract by either party has always been unambiguous. The position is that such a violation is unacceptable and violates the principle of contractual stability enshrined in the FIFA Regulations on the Status and Transfer of Players (Article 17). It can be assumed that FIFA believes that its opinion has already been formulated and expressed in the decision that was made on this dispute by the FIFA Dispute Resolution Chamber and is appealed to the CAS.

It is also worth noting that the mediation procedure is not universal. Of course, it should be noted that at present the scope of application of mediation has gone far beyond the traditional for this procedure contractual disputes, for example, mediation is gradually applied to resolve administrative and tax disputes. This should be taken into account, determining in each individual case the possibility of applying mediation in disciplinary disputes. Perhaps FIFA did not to enter the mediation procedure because one of the requirements was the application of disciplinary sanctions to the football player or to the club in the cases Arbitration CAS 2014/A/3643 and Arbitration CAS 2014/A/3707. However, the absence of any reaction and explanation of its position allows one only to make assumptions about this.

In the case Arbitration CAS 2015/A/4220 Club Samsunspor v. Aminu Umar \& Fédération Internationale de Football Association (FIFA), award of 12 July 2016 notes that according to the provision of paragraph 4 of Art. 17 of the FIFA Regulations on the Status and Transfer of Players imposing sporting sanctions on the club that has broken a contract with players is the responsibility of the competent authority, and not its right, therefore it can not be the subject of a mediative procedure. It is worth noting that this decision was made by the mediator, who was chosen by the parties to resolve the dispute over the unilateral termination of the employment contract with the player. It is paradoxical that, in the event that the parties nevertheless managed to agree on a settlement of the dispute through mediation, the chosen mediator informed them that it was impossible to apply an alternative way of resolving the conflict in their particular case.

Success of the application of the mediation procedure in the case Arbitration CAS 2014/A/3850 Branislav Krunic v. Bosnia and Herzegovina Football Federation (BIHFF), award of 17 July 2015 was not assured. In the dispute footballer Branislav Krunic appealed to the CAS with demands to abolish the decision of the Committee of the Football Federation of Bosnia and Herzegovina on the Status and Transfer of Players, a decision not made in his favor. As the only defendant in this dispute, the player named the Football Federation 
of Bosnia and Herzegovina (BIHFF), which agreed to the use of mediation, however, the mediator did nothing but recognize the impossibility of resolving the conflict. In the dispute as a party was not attracted to the football club with which Branislav Krunic a conflict situation arose. Any other conclusion would clearly violate the right of the club to be heard and deprive it of a chance to protect its interests (comment on the arguments of the applicant, provide evidence and etc.). Also, the CAS mediator notes that CAS decisions apply not only to FIFA and regional football federations, but also to individuals (athletes, coaches, agents, referees of matches, etc.) or legal entities (clubs, investment companies, etc.).

This example clearly demonstrates that parties wishing to resort to mediation must be the parties to the dispute, authorized to conduct a constructive dialogue to find a mutually beneficial solution. Thus, there is an important conclusion that mediation is not allowed to go beyond the legal boundaries. Mediation allows you to regulate what, according to the normative act, is possible outside of mediation. Mediation should not be a way of circumventing the norms of the act and violation of the rights, legitimate interests of third parties (in the decision this amounted to the rights of the football club, against which the applicant had a claim).

As an example of the successful application of the mediation procedure in a sports dispute the decision in the case Arbitration CAS 2015/A/4148 \& 4149 \& 4150 Sheffield Wednesday FC v. Louletano Desportos Clube and International Clube de Almancil \& Associação Academica de Coimbra, award of 17 February 2016. In this decision, FC Sheffield Wednesday requires changing the amount of payments that the club must pay to clubs that participated in the training and education of the player, the right to register that it acquired. This case is an illustration of how the parties to the conflict know how to value their time and that of their opponents. All persons involved in the dispute approved the consolidation of several cases into one proceeding due to the identity of the subject matter of the dispute, and expressed their readiness to resort to the mediation procedure. The dialogue was not only about the amount of compensation to each of the three clubs, but also about determining the status of the player (professional or amateur), which directly affects the size of the above payments. We cannot fail to note the role of CAS mediator, which concluded on the status of the player, determining that the status should be analyzed solely on the grounds specified in the relevant FIFA rules (FIFA Regulations on the Status and Transfer of Players), without national legislation. The mediator noted that this primacy exists for both international and intranational transfers. Consequently, the definition of a player's status is fundamentally excluded as the objective of mediation, because this is in the competence of the CAS. Only after arbitration determines the status of the football player, will it be possible to argue over the amounts of reimbursements connected with the transfer of this player that are due.

In conclusion, it should be noted that alternative dispute resolution is a general legal trend and is becoming more widespread in world practice. This reflects the concept of access to justice in combination with maintaining the level of guaranteed protection of the interests of the parties.

Mediation applied in the field of sports disputes must undoubtedly meet the fundamental principles of alternative conflict resolution, one of which is freedom to conclude an agreement on the use of mediation, voluntariness and trustful of relations. Forcing parties into mediation is impossible, the choice of the mediation procedure by parties to the conflict must be deliberate. 
Mediation means overcoming the conflict "in good faith", so it is impossible to enforce the decisions reached during the mediation (Sevastyanov 2009, 166).

This approach to mediation is reflected in CAS solutions. For example, in the case Arbitration CAS 2014/A/3642 Erik Salkic v. Football Union of Russia (FUR) and Professional Football Club Arsenal, award of 8 April 2015, in which the arbitral tribunal considered that the procedure for considering the disputes in the jurisdictions of the Russian Football Union namely the Chamber for Dispute Resolution, is not mediative. This problem arose because of the different interpretation of the word "arbitration". In the narrow sense, this is exclusively an arbitration trial, the resolution of a dispute with the help of an intermediary. In a broad sense, the term "arbitration" is also used to refer to a judicial procedure with a professional judge. In support of this, the CAS pointed out that this body of the sports tribunal is not an intermediary body and its decisions are binding, they are enforced, moreover, they become final, if there is no further appeal in due time. Another approach of CAS would violate the voluntariness and reliability of the procedures that are hallmarks of mediation.

In addition, for mediation it is crucial the parties to the process agree on their positions, the impossibility of dominance in the process of business communication and impose their line of conduct.

In this regard, it can be noted interesting fact that in six of the eight cases examined (Arbitration CAS 2014/A/3580 A. C. Cesena S.p.A. v. Tokyo Football Club, award of 24 December 2014, Arbitration CAS 2015/A/4057 Maritimo da Madeira Futebol SAD v. Al-Ahli Sports Club, award of 30 November 2015, Arbitration CAS 2014/A/3679 FC Dacia Chisinau v. Goran Stankovski, award of 27 February 2015, Arbitration CAS 2015/A/4346 Gaziantepspor Kulübü Derneği v. Darvydas Sernas, award of 5 July 2016, Arbitration CAS 2015/A/4220 Club Samsunspor v. Aminu Umar \& Fédération Internationale de Football Association (FIFA), award of 12 July 2016, Arbitration CAS 2014/A/3643 Club Promotora del Pachuca S. A. de C. V.v. Facundo Gabriel Coria and FIFA, award of 5 June 2015) of unsuccessful mediation the parties could not agree at the very beginning of its phase, namely, they could not decide at whose expense the procedures would be conducted and, in two of them (Arbitration CAS 2014/A/3580 A. C. Cesena S. p.A.v. Tokyo Football Club, award of 24 December 2014, Arbitration CAS 2015/A/4057 Maritimo da Madeira Futebol SAD v. Al-Ahli Sports Club, award of 30 November 2015) each of the parties actively tried to impose costs on their opponent, arguing that they were responsible for them. It is not surprising that the conciliation procedure for these cases did not take place: it is difficult to discern the ground for constructive business communication in such situations.

At the same time, in those three cases where the parties managed to reach a decision on the settlement of the conflict situation by the mediation procedure (Arbitration CAS 2015/A/4220 Club Samsunspor v. Aminu Umar \& Fédération Internationale de Football Association (FIFA), award of 12 July 2016, Arbitration CAS 2014/A/3850 Branislav Krunic v. Bosnia and Herzegovina Football Federation (BIHFF), award of 17 July 2015, Arbitration CAS 2015/A/4148 \& 4149 \& 4150 Sheffield Wednesday FC v. Louletano Desportos Clube and International Clube de Almancil \& Associação Academica de Coimbra, award of 17 February 2016), the payment for the services of the mediator is assigned to an applicant or the parties divided the costs equally.

The possibility of applying mediation has certain limits. Thus if the issue is imperatively normatively settled without the parties' ability to show discretion, then the possibili- 
ties for using the mediation procedure are simply not foreseen. Therefore, two cases were not crowned with the successful use of mediation (Arbitration CAS 2014/A/3643 Club Promotora del Pachuca S. A. de C. V.v. Facundo Gabriel Coria and FIFA, award of 5 June 2015 and Arbitration CAS 2014/A/3707 Emirates Football Club Company v. Hassan Tir, Raja Club and FIFA, award of 19 June 2015) in which the parties (the club and the player) wanted to settle, among other disputes, the application of sanctions to them, but FIFA, being one of the defendants, ignored the proposal to start the mediation procedure. Mediatory procedures were not conducted in the case (Arbitration CAS 2015/A/4220 Club Samsunspor v. Aminu Umar \& Fédération Internationale de Football Association (FIFA), award of 12 July 2016) in which the parties managed to agree on the use of mediation instead of the CAS proceedings, but the mediator was forced to admit that the parties have no right to agree on sanctions, since there is a normatively established procedure for their application.

However, it should be noted that in the field of sports disputes, mediation has its own characteristics, for example, greater opportunities for application. For example, CAS did not see obstacles to mediation in the case, the subject of which was the calculation of the payment of solidarity, although the procedure for its calculation is detailed in the rules of FIFA.

Despite the growing popularity of using alternative dispute resolution procedures, there seems to be some mistrust towards them, including in sports disputes. For example, in two decisions (Arbitration CAS 2014/A/3679 FC Dacia Chisinau v. Goran Stankovski, award of 27 February 2015 and Arbitration CAS 2015/A/4346 Gaziantepspor Kulübü Derneği v. Darvydas Sernas, award of 5 July 2016) on the unilateral termination of the player's contract with the club, the players categorically refused to offer clubs to resort to the mediation procedure, although its advantages are difficult to dispute - saving time, money, maintaining business reputation. Apparently, despite this, it was not possible to overcome their perception as an "anarchic element" to the end.

Although it is worth noting that gradually the attitude towards mediation in the field of sports disputes has begun to be viewed as a full-fledged way to resolve the current conflict. Such a conclusion can be made on the basis of the fact that, in seven of the eleven cases examined, it was one of the parties who initiated the process of mediation, in three of which the second party supported the proposal. Basically, these were sports clubs that are professionals in this market, which it is important to preserve not only their own funds, but also their own name. It seems that such a trend is not accidental. Mediation initially arose and is most commonly applied in the sphere of commercial relations, for the most part among major business actors (Abramson 2011). In the field of sports relations, such large actors are football clubs.

As a result, attempts to apply mediation are adopted in various conflict situations in the field of sports disputes, from the requirements arising from the relations of the subjects of sports, to the requirements concerning the control and application of disciplinary measures, to which any conciliation procedures are not inherent in the general rule. FIFA and UEFA are expressing their desire to replace the trial with an alternative dispute resolution in the implementation of regulation, monitoring of players, clubs, national associations and their officials. This is a reflection of the worldwide trend of mediation with the participation of authorities in disputes that go beyond commercial relations, for example, when settling tax and administrative conflicts. 


\section{References}

Abramson H. 2011. Mediation representation. Oxford: Oxford University Press.

Court of Arbitration for Sport (CAS). Accessed July 14, 2017. http://www.tas-cas.org/en/mediation/rules. html.

Folberg, J. 1994. "Alternative Dispute Resolution: An Empirical Analysis." Stanford Law Review: 46.

Lawrence, E. Susskind, David Kovick, Kate Harvey, Jennifer Brown. 2009. Teaching About the Mediation of Values-Based and Identity-Based Disputes: A Teaching Note. Accessed July 14, 2017. https://www.pon. harvard.edu/shop/values-based-mediation-simulations.

Mordehai, Mironi. 2017. "The promise of mediation in sport-related disputes." The International Sports Law Journal 3-4: 131-154.

Sevastyanov, Gleb V. 2009. Source Book of Alternative Dispute Resolution: Training materials and best practices: arbitration; international commercial arbitration, mediation: a tutorial. St. Petersburg: ANO "Editorial Board of "Arbitral Tribunal".

The UEFA Club Financial Control Body (CFCB) Cases. Accessed July 14, 2017. https://www.uefa.com/ insideuefa/disciplinary/club-financial-controlling-body/cases/index.html.

Received: 05.10.2017

Accepted: 30.11.2017

Author's information:

Shabalina Ekaterina A. — Independent Researcher; shabalina-1996@mail.ru 